\title{
Eschatological Expectations in a Changing World: Narratives About the End of the World in Present Day Russian Folk Culture
}

\author{
Aleksandr Panchenko. \\ Institute of Russian Literature, St. Petersburg
}

It is not necessary to prove that eschatological teachings and beliefs play an important role in all Christian confessions. It is just as obvious that the form these beliefs take depends on the cultural and historical context. On the one hand, ideas about the end of the world and about the fate of humanity serve as an object of professional interpretations of the Bible, ecclesiastical works, and apocryphal literature. On the other hand, eschatological ideas and beliefs actively function in an unspecialized folklore context, at times exerting significant influence on everyday communication. I will discuss this latter aspect of eschatology and will use it to arrive at a deeper understanding of the social and cultural functions of the "last days" in the Orthodox tradition. The material for this study consists of ethnological data referring mainly to Russian peasant culture from the end of the nineteenth century into the twentieth. Available data permits speaking about a special type of eschatological narrative that was characteristic for the Russian peasantry of this time. Such texts cannot be understood outside the features of their performance. Therefore, analysis of adequately recorded and well documented stories, in particular present day field materials, receive special significance.(1)

Some preliminary remarks are necessary. The material can be grouped into two generalized, traditional types of "Eschatological" behavior. The first is represented by eschatological expectations which do not exert a fundament influence on the way of life or the behavior models of their bearers. Peasant, aristocrat, Orthodox church member, and Old Believer can anticipate that the world will end some day and still behave as normal members of society, carrying out their customary social and economic duties. The other type can be called eschatological movements whose participants consider the end of the world has already begun or is immanent. They are convinced that it is necessary to abandon their traditional way of life and to change their behavior radically. The consequences of these movements, which are usually headed by a charismatic leader (or leaders), can be quite diverse, ranging from mass suicides to armed rebellions. Of course the two types of eschatological behavior are not isolated from each other and they often interact. Nonetheless, each of them has its own specific traits.

The texts under consideration belong to the first type of behavior. "Folk hearsay" the end of the world, the Antichrist, and Judgment Day have often been the subject of Russian folklore and ethnographic literature.(2) However, only one work has been devoted specifically to analysis of this material(3), a recent article by A. F. Belousov(4). It is based on folklore recordings made in the 1970s among Russian Old Believer bespopovtsy [those without a priest] in the South Baltic Region. The analyzed texts, however, are 
characteristic not only for the Old Believer tradition (at least in the twentieth century). Investigating the eschatological statements made by the South Baltic bespopovtcy, Belousov departs from two methodological principles. First, he tries to discover a correlation between present day folk expressions about the "last days" and "ancient eschatological imagery." By the latter the author means symbols found in written apocalyptic texts (both canonic and apocryphal). However, the author points out that "a proper understanding" of this imagery "is often absent among the informants"(5). Second, he simultaneously undertakes a synchronic analysis of the eschatological views of the informants and a search for bookish prototypes. As a final result, his analysis can be reduced to determination of basic concepts and oppositions which can be correlated with ideas about the end of the world.

Although the methods used by Belousov suffice to analyze folk eschatology, they can not be considered to be comprehensive. First of all, they do not allow firm statements to be made about the functions of the eschatological texts being interpreted(6) as well as about their morphology and typology. In addition, they provide predominantly structural (i.e. universal) explanations of those images and motifs which have no direct prototypes in written works. Finally, even in regard to borrowings from written sources, apparent or not, it remains unclear precisely why they were incorporated into folklore texts.

The question about the correlation of oral and written forms in Russian folklore in general and folk religious traditions in particular requires special reservations. Since the work of A. N. Veselovskii and his followers on the subject of Christian legend and religious verse, this problem has been considered in connection with the dynamics of individual motifs and plots that have passed from written texts to folklore, or, vice versa, from an oral to a written literature. However, a rather large number of difficulties exists. First, historical-genetic analysis allows establishing the fact of borrowing and, in some cases, determining the historical conditions of the latter. The social and cultural reasons for these processes, as a rule, can not be explained from such a perspective.

Besides this, it is not always clear, whether we are dealing with a borrowing from a specific written work or simply with a realization of a traditional culture topic. This question has special importance when oral and written eschatological legends are compared insofar as both abound in "common places" which mark violations of the boundaries of social and anti-social, and which involve typical descriptions of natural anomalies. Besides all this, it often turns out to be unclear whether "the vector" of primary borrowing was directed from written work to oral literature, or vice versa. Students of Christian eschatological literature have frequently emphasized the "purely folk character" of individual episodes in apocrypha and legends about "the last days"(7).

Finally, there exits another, to some extent paradoxical, type of interaction between oral and written traditions. This presumes that what is being deduced from a written text (or ascribed to it) has no correlation to its real contents. On the one hand, such reading is supported by the norms of "peasant hermeneutics"; on the other, it is conditioned by religious and mythological ideas about the role of written 
literature in general and books in particular. In spite of fact that bookish citations are sometimes found in eschatological narratives by Russian peasants, their relative weight is low in comparison with pseudobookish citations.(8)

Thus, the task of explaining the contents and specific functions of a folk eschatological story can not be achieved exclusively by historical and literary methods. In my opinion, the most important question here concerns the correlation between the contents of such texts and the mechanism of their generation, i.e. traditional means of narration. In this regard, we will examine the narrative structure of a present day eschatological story.

It seems that investigators who always try to find written sources for various motifs in folk eschatological narratives are often led astray precisely by the paradox of pseudo-bookish attribution. According to present day field observations, most informants emphasize the bookish origins of the eschatological information known to them. (It is curious that such attribution of eschatological predictions is equally characteristic for Orthodox Church members and for Old Believers, although the role of reading differs in each group.) A story about the end of the world can be communicated not only after an interviewer's questions, but also during a conversation about prayers known in the family of the informant, or about books being kept in the village. The following are several examples.

You see, many centuries have passed, and it is just so in writings, it is in writings. Well, I ... what is there to say, am semi-literate, but my grandfather was literate, he had a Bible. Have you heard about that book? And he read it. It goes up to the second millennium, it has been described for two millenniums. Well, everything has been written about this. All that has been written is just true.(9)

They say then there is the Bible, there was such a book. $<\ldots>$ Whether it is a church book, I don't know. Some clever man has written it, this Bible. And it had been written so, that ... it . . . so it has just come to pass, it is just so.(10)

I have only heard that it ... that old woman ... it has prayers . . little books ... here they read these ... . how are they called ... That's what they read ...(11)

$\ldots$ Yes the end of the world. My mama said my grandmother was with them ... she was old. She no long could see - well, she would talk, would call us. We were little, there were three children. She would call us, would speak, and would stroke us on our heads. "You're really too small," she would say, "I would tell you many things, would teach you." Then she would say that she had read the Bible, what would happen, then all this began, the whole country, the whole 
land was entangled with wires. You see earlier they didn't understand that there would be wires, that's what all these were.(12 )

These are typical openings for apocalyptic stories. Here the "Bible" is presented as a generalized image of a sacred cosmological book which can be compared with the golubinaya kniga [book of the dove] and with "the Jerusalem manuscript" of Russian religious verses and legends. The information contained in it requires special decoding, something which brings to life the figure of the "literate villager" (or "old women"), telling his neighbors about what he has "read." It is indicative that the Bible is equated with books and "prayers" in general, and - from a wider perspective - with manuscript collections of "charms," i.e., "sorcerer's" writings. Thus, a written text having a magical character is considered to be a source of eschatological information.(13)

Another important feature in the performance of present day eschatological narratives is the discussion of signs about the end of the world as coming true or having come true. Here certain rhetorical turns with fixed framing formulas such as "it is just so" or "it has just come true" are used:

That the wide world, they say, would be covered with webs. Here it is covered with wires. Here it is. Son, they say, will beat his father and ... or the father will beat his son. Well that's the way it is: brother kills brother.(14)

And everyone always said, those who read, that there would be such a time, that people would devour each other, and people would live several kilometers from each other, and there would be iron horses - daughters, just as it is! Now here comes a tractor, it mows, it rakes, it makes bales - people are no longer needed. Isn't it true? That's how it has come about now.(15)

There was a book "Paradise lost and returned." How people were born and that everything on earth as it is now is written there. That a woman will wear man's clothes, will get drunk to the point of madness, that Satan will sit on throne and will look around and point out what is done from all countries. That's the way it is now.(16)

It appears that the generation of such texts is connected with the idea of prophecies having come true. In other words, the source of eschatological hearsay is usually not found in motifs from the Christian apocrypha, which are being compared with actual events, but derive from the events themselves, which are constructed as signs of the end of the world. Unfortunately narrative analysis can be applied only to texts collected according to methods of field recording that have become widespread only in the twentieth 
century. However, it is entirely possible that the mechanisms for generating eschatological stories were similar, if not the same, among peasants during the last part of the nineteenth century.

Now let us turn to the contents of the texts under consideration. Proceeding from the reasons mentioned above, I shall discuss corresponding images in accordance with their interpretative sense instead of their possible apocryphal sources. Several groups of motifs can be distinguished. The first is connected with an interpretation of technological innovations. Most stories recorded in the twentieth century mention an earth covered with "webs" (corresponding to electric wires or telegraph lines - if the text was recorded in the beginning of the century) and flights of "iron birds." When speaking about the latter, informants usually indicate planes, but the notion about iron beings can be spread to other aspects of technology.

Here lived this Vovochka and he had a Bible. And he said that . . he would sit on a bicycle . . . on a bicycle . . . he would sit . . . a guy, he would take it between his legs and would ride off. And people said to him: drop it, how could he ride! Then there were no bicycles, nobody knew about such bicycles. A bird, he said, will fly . . . made of iron. Well, they said, what have you thought up! . . And all this is there in the Bible, he had a Bible and he spoke, he told about this.(17)

The mechanism of interpretation is obvious: the image of iron birds is used to add eschatological meaning to technology, and the image of the earth covered with webs is employed to conceptualize electricity and, possibly, means of mass communication. In passing, it can be remarked that the same perception of telegraph wires was noted in the Kostroma Provence in the 1910s.(18) It is obvious that Esenin's lines about "the stone hands of a highway" "squeezing the countryside's neck" both typologically and chronologically belongs to the same kind of imagery.(19) The image of iron birds has special interest in this context. I have not met any direct correspondence to it either in eschatological apocrypha or in canonical texts. With some allowance, the notion of iron birds could be correlated with the image of apocalyptic locusts ("And they had breast-plates, as it were breastplates of iron; and the sound of their wings was as the sound of chariots ..." (Revelations 9, 9) or with the "dog's flies" from the apocryphal "Word of the holy prophet Isaiah, the son of Amos" ("They will eat your flesh and drink your children's blood and tear out your infants' eyes")(20). It would be natural to assume that iron birds have appeared in the present day eschatological narrative because of the spread of airplanes. Moreover, balloons and zeppelins at the end of the nineteenth and in the beginning of the twentieth century had been perceived by Russian peasants as a sign of "the last days."(21) However, the notion that birds with iron beaks "will torment people before the end of the world" was recorded in Orel Provence in the 1860s even before the beginning of air flight.(22) In some prose variants of "The Jerusalem Manuscript"(23) relating to the same time, birds with "iron noses" are also mentioned among the future punishments for mankind's sins: "If you are unrepentant I shall open My mouth and inflict you with thunder, lightning, hail and famine, great 
darkness, and black birds with iron noses that will peck you."(24) This image apparently has more archaic folklore roots. Without mentioning all possible analogies,(25) we can limit ourselves to the closest examples, i. e. the imagery of the Russian magic tale. "Black ravens, iron noses" carry the servant to the mountain in the variant of the story "Golden Mountain" (AT 936) which A. N. Afanasev published.(26) In his variant of the tale "Neznaiko" (AT 532) the stepmother goes to kill the magic horse and says: "Let him croak! Thirty three ravens with iron noses will come flying here, they will peck out the flesh and will take the bones to the edge of the world!'(27) Finally, in the tale about marvelous gifts (AT 563) recorded on the Tersk shore of the White sea, "a bird with an iron nose and wooden tail" figures as a giver: "The old man took out his axe and went to the forest, he struck a tree, he struck another, then a bird with an iron nose and wooden tail jumped out."(28) Evidently, "birds with iron beaks" appear in the magic tale as representatives of the other world, they are often hostile to people, and are unequivocally connected with the symbolism of physical death. Thus the eschatological image of iron birds / birds with iron beaks appears to be heterogeneous since it may be influenced by different narrative traditions. However, its extraordinary dissemination in present day peasant narratives about the end of the world can be explained only by the interpretative functions of the latter.

Another group of motifs describes social disorders in the rural world: enmity between blood relatives, drunkenness, or robbery. On the one hand, traditional eschatological topics are reproduced here: the vast majority of legends about the end of the world predict the destruction of the habitual norms for public order as preceding "the last days." On the other hand, here we are also dealing with a particular social and age effect involving the conceptualization of the dynamic aspects of rural life. All coming changes are inevitably described by representatives of older generations as ethic deviation. These motifs are supported by a rather extensive group of formulas that contrast "old times" and the present day in special idealistic stories about "the past" and formulaic lamentations about "the present": "the devil no longer possesses us, but people possess the devil," "they don't believe in God now, they believe in devil." Both can be reproduced outside an eschatological context, but their closeness to hearsay about the end of the world is undoubted. However, this problem deserves special analysis.(29)

The third group has a more universal character. It concerns notions about a small number of people on the earth and their physical weakness: "two people will remain for each one hundred kilometers, and they will look for each other," "people will look for each other for each one thousand kilometers," or "two people will carry a venik (a switch of birch twigs) to the bathhouse." Sometimes the direct influence of eschatological writings can be traced. Thus the prophecy about people who can find room on a seven-meter tree evidently has its origin in the story about widows known according to the interpolated wording of the "Revelation of Methodius of Pathar" and "the life of Andrew the Urodivy" [holy fool].(30) Many features in these notions indicate their close connection with the aspects of peasant cosmology known in local legends. In a certain sense they are a symmetric parallel to North-Russian legends about settling the territory 
and about the physical strength of ancient people. Thus, according to one of the typical motifs in legends about founding villages,(31) one of the settlers learns about existence of another settler by a venik or pomelo (whisk) floating down the river (more rarely by chips, rubbish, or feathers).

Here our grandfather said - "I heard it myself" - that supposedly somewhere higher up there was a house, alone. And here, a little farther, another. And a whisk floated to this house. That is what this event began with. A whisk came floating. $<\ldots>$ So this owner went by this whisk to look for the supposed house. This means, there were inhabitants somewhere since a whisk came floating by (it used to be, everybody had a whisk, and when it would become bad they would throw it out. So they threw this whisk in the river). So he went and found, as people said, another house. A second owner lived there. So that's how things started there $\ldots<\ldots>$

The name of the first resident either was Khristov or some kind of . . .

The first house was in Ilomancha. There was one here too, only it's unknown, in what place, somewhere here, in Ladva. But I don't know, in what place.(32)

Thus the people of "the last days" are described in a present day eschatological story with the same cosmological motifs as the "first people," although, so to say, "with a different sign." In connection with the same group of notions, it is necessary to mention the motif of "the measured earth"(33) which is often used as a token of the end of the world. It implies that "during the last days" "the whole earth will be measured in vershki or piadi."(34) A. F. Belousov assumes that this notion "is a distinctive form for assimilating the idea about the predestination of 'the end of the world,' which will to come as a result of calculating the measure (number) lying at the basis of the world."(35) However, it appears that the determining role is not played by the speculative idea of the universe being calculated, but by a traditional ritual practice of measuring the human body.(36) The latter could be oriented both toward constructing a "ritual double" of a person and by acquiring magic power over his body. Apparently the motif of measuring the earth (or land) in the stories being examined derives precisely from this circle of ideas and presumes "alienation" of the earth, and its submission to external and hostile forces. Besides this, a definite role could be played by anthropomorphic worshipping of the earth which has been characteristic for the Russian peasant tradition.

It is likely that the direct stimulus for emergence of this motif in eschatological folk hearsay was played by P. A. Stolypin's agrarian reform which destroyed traditional land community and initiated division into private plots of land. However, in present day eschatological stories the measuring of earth (land) is associated with collective farm nationalization, which was the complete opposite to Stolypin's reform. 
He said that the whole land would be measured in vershki: there would not be individual, but common ownership of the land.(37)

It has all come true. Boundaries - what boundaries? Those boundaries! There were individual plots before, and this boundary ... here is what they're doing, they will make ... boundaries, raise, and harvest. Well, that's what they thought up! But it has just come about: they made collective farms, they began making boundaries, tying knots: you harvested just so much, I harvested just so much.(38)

A definite connection with the traditional semantics of measuring can be observed in the eschatological interpretation of the general census in 1897. Such an attitude toward the census was reported among the peasants of various regions in European Russia. However, the determining role was apparently played by the Old Believers' idea about “Antichrist's seal”(39):

... The schismatics saw the meaning of the census as a precursor of the Antichrist even in the very census lists. Two kinds of them, A and B, were set aside, in their opinion: one was for the followers of the Antichrist and the other was for the followers of God. Those who conducted the census told how they had been intensely asked and implored to be included in the B list and not in the A list. Here and there the schismatics, as soon as they heard about the general census, began to organize meetings at which they unanimously decided that this census was a sign of the presence and manifest enthronement of the Antichrist in the world and a snare for his acceptance. For this reason it was necessary to avoid the census by all possible means.(40)

It should be added that the Antichrist, as a rule, does not figure in the eschatological narratives recorded during the second half of the twentieth century, differing from those in the last part of the nineteenth century. It would be possible to assume that the difference resulted from the peasants' lowered level of religious instruction in the Soviet period, but the same picture has been observed among Old Believers among whom the level of religious erudition has been more stable.(41) Belousov explains this situation by the Old Believers' theory of "the spiritual Antichrist," but it seems to me that this could scarcely have exerted any significant influence on the folklore tradition. It is more likely that the reasons are also enrooted in the social and historical dynamics of Russian folk culture in the nineteenth and twentieth centuries. Messianic legend and hearsay about the Antichrist presume a correlation of eschatological ideas with one or another historical (or pseudo-historical) figure being the central personage of a legendary subject. The ambivalence of this kind of ideas is demonstrated by folk ideas about Napoleon whom they could perceived both as the Antichrist and as Christ. A special sect of Napoleon worshippers even existed in 
Moscow in 1840-s. The events of the early decades of the twentieth century apparently changed the social and state priorities of the peasantry: impersonal hostile forces replaced a personified Antichrist.(42)

Finally, let us turn to the very end of the world. It is curious that present day eschatological narratives frequently do not describe it (much less succeeding events). The description is limited by a list of possible signs ("there will come such a time that people will seek each other for a thousand kilometers - and to find them ... This will be the end of the world"). If the description is nevertheless present, Judgement Day is often replaced by a simple renewal of the world, which, generally speaking, is more characteristic for the eschatological myths of primitive peoples.(43) Thus, for instance, one married couple living in the northern part of the Novgorod region offered the following interpretation of the desolation and renewal to come:

Wife: That's how Adam and Eve will remain, then it will be so, maybe, just so again, then it can and will be so.

Husband: Then, maybe, they will slowly start again.

Researcher: That is, only two people should remain?

Wife: Yes.

Husband: They must find room on a tree of seven sazhen.

Wife: There will remain as many people, as can find room on a tree of seven sazhen.(44)

The present article does not exhaust all the thematic and compositional aspects of the folk eschatological narrative in the nineteenth and twentieth centuries. However, the presented materials are sufficient to speak about the tendencies that have been traced here. The folk explanations of the "last days" use both motifs of traditional cosmology and themes of Christian eschatological writings. However, at the same time the peasants' eschatological narrative creates a special kind of imagery which fulfills an interpretive function. On the one hand, the signs of the end of the world are described as having happened; on the other hand, a certain sacred cosmological text is construed as their source.

It seems that the basic meaning of folk stories about the end of the world consists of an adaptive interpretation of the dynamics in social life, i. e., changing forms of day-to-day life or innovations of a technological character. Thus an eschatological story turns out to be one of the main means of macro-social conception existing in Russian rural culture at the end of the nineteenth and in the twentieth century. In other words, when a present day peasant faces a problem of understanding social reality, which is beyond the bounds of the habitual forms of everyday life, he resorts to the interpretative mechanism of an eschatological narrative. The same role was apparently played by messianic legends "about deliverers" in the eighteenth and nineteenth centuries, peasant hearsay about "freedom" and "distant lands."(45) How such a mechanism of interpretation works can be demonstrated in examples of two eschatological stories which 
juxtapose the image of apocalyptic horsemen (Revelation, 6, 1-8) and episodes of most recent world history:

And this was according to the Bible that two cocks would fight, you see. Well, the red will win. Well, we defeated Germany.(46)

Informant: That's what will be ... and at first, they say, they said, that it was written in . . .$:$ the red horse will trample the white one, and then the white one will trample the red one. That's to say it turned out. A lot of years have passed. We won the Great Patriotic $<$ War $>$... All the same the red horse overcame. But the white horse won without a war. It destroyed everything.

Researcher: And what is the white horse?

Informant: Well, democrats. America. Everyone. They smashed the Soviet Union . . . you see, the Soviet Union was strong, but they smashed it in a moment. Everything went to pieces. All the communists have changed into these bureaucrats.(47)

Why does a social and historical conceptualization of present day Russian peasants acquire precisely an eschatological coloring? The reasons for this deserve special investigation. It is possible, of course, to speak about the reaction of peasant conservatism ("tradition") to the dynamics of urban culture. It also is possible to propose that social self-description of Russian peasants in the nineteenth and twentieth centuries inevitably presumed a certain historical doom. Finally, it is possible, following M. Eliade, to discuss the universal functions of eschatological myths. But it is obvious that this "naive sociology" assumed and continues to assume a deeper sphere of meanings than it is accepted to think. In Russian historiography the sole attempt to analyze consistently the social determinants and functions of peasant legend belongs to K. V. Chistov. However, he, for entirely understandable reasons, limited himself to rather vague judgements: utopian legends and movements "are engendered by despair and hope," "they result from realization about the impossibility of living in contemporary conditions and from a hope for a social miracle"(48), and that they represent "an individual syncretic variant of folk journalism," which expresses a "negative" social ideal characteristic for the peasantry during the crisis of feudalism.(49) Meanwhile, it is obvious, that the interaction of folklore texts and the practices of everyday life with social structures has a sufficiently complex and variable character.(50)

It seems, that the above mentioned eschatological expectations of the Russian peasantry, having functioned during the twentieth century in the form of narratives about "the last days," are, to an essential degree, connected with processes of acculturation, i.e., in a technological sense the influence of a more highly developed culture on a less developed culture. Such processes, which are accompanied by a change in social structure and reorganization of axiological systems, inevitably cause a specific social tension. It is 
often expressed by different messianic movements. A classical example of such movements concerns Melanesian "cargo-cults," which became widespread in the first half of the twentieth century. Their basic content was reduced to an expectation of large ships which were loaded with numerous goods and on which their ancestors were to arrive. After the appearance of the ships the golden age was to begin: all the colored were to become white, abundance was to reign, and work would not be necessary. Waiting for the ships and ancestors was accompanied by deliberate neglect of traditional ritual and everyday norms, and also by an imitation of the whites' behavioral practices. Both legends and rituals connected with the cargo-cults represent a whimsical mixture of traditional mythological and ritual models and motifs of Christian dogma.(51)

Although the cited eschatological narratives differ considerably from messianic legends of the Melanesian natives,(52) they coincide in one point: their main function consists in the adaptation of cardinal changes in social structure under the influence of an alien civilization having a technological character. In both a simple translation of meanings from the language of one culture to the language of another is not taking place, but instead principally new semantic constructions are being formed. At the same time, the utopian optimism of the Melanesians has led to a short duration of their messianic movements, while the pessimistic mood of Russian peasants has ensured a rather stable reproduction of eschatological narratives through several generations.

\section{NOTES}

1. Besides published data, field recordings from 1997 - 1999 will be used - they are preserved in the archives of the Ethnology Department of the European University in St. Petersburg (henceforth EUSPb) and of the Folklore Cabinet of the Philological Faculty in St. Petersburg University (henceforth FK $\mathrm{SPbGU})$.

2. A. N. Trunov, "Poniatiia krestian Orlovskoi gubernii o prirode fizicheskoi i dukhovnoi" [The ideas of the peasants of Orel Provence about physical and spiritual nature], Zapiski imperatorskogo russkogo geograficheskago obshchestva po otdeleniiu etnografii, t. II, 1869, p. 41-42; M. A. Ivanitskii, "Materialy po etnografii Vologodskoi gubernii" [Materials on the ethnography of Vologda Provence], Izvestiia obshchestva liubitelei estestvoznaniia, antropologii i etnografii, t. 69: "Trudy etnograficheskogo otdela" t. 11, vyp. 1 (Sbornik svedenii dlia izucheniia byta krestianskogo naseleniia Rossii, vyp.II, pod red. N. Kharuzina), Moscow, 1890, p. 118; P. L. Iudin, "K istorii russkogo raskola" [Toward the history of the Russian schism], Russkaia Starina, 1894, no. 1, p. 182-86; M. Dikarev, "Tolki naroda" (Antikhrist Myshiny tsar - Gadiuki) [Hearsay of the people (Antichrist - Mouse tsar - Vipers], Etnograficheskoe obozrenie, kn. XXIV, 1895, no.1, p. 125; M. Dikarev, “Tolki Naroda v 1895 g." [Hearsay of the people in 1895], Etnograficheskoe obozrenie, kn. XXVIII, 1896, no.1, p. 144-46; M. Dikarev, "Tolki naroda v 1899 
godu" [Hearsay of the people in 1899], Etnograficheskoe obozrenie, kn. XLIV, 1900, no.1; D. N. Ushakov, "Materialy po narodnym verovaniiam velikorussov" [Materials on the folk beliefs of the Great-Russians], Etnograficheskoe obozrenie, kn.XXIX-XXX, 1896, no.2-3, p. 196; V. G. Suvorov, "Religiozno-narodnye poveria i skazania (Zapisany v Kaliazinskom uezde Tverskoi gubernii)" [Religious folk beliefs and legends (Recorded in the Kaliazin district of Tver Provence]," Zhivaia Starina, 1899, vyp. III, p. 394; A. I. Ivanov, "Verovaniia krestian Orlovskoi gubernii" [Beliefs of the peasants of Orel Provence], Etnograficheskoe obozrenie, kn.XLVII, 1900, no.4, p. 70; V. Smirnov, "Otnoshenie derevni k voine" [The attitude of the village toward the war], Kostromskaia derevnia v pervoe vremia voiny (Trudy Kostromskogo nauchnogo obshchestva po izucheniiu mestnogo kraia, vyp. V), Kostroma, 1916, p. 123-24; Iv. Kostolovskii, "Narodnye poveria zhitelei Iaroslavskogo kraia" [Folk beliefs of the residents of the Iaroslavl' land], Zhivaia starina, 1916, prilozheniie no. 5, p. 40-47; N. E. Mazalova, "Narodnaia meditsyna lokalnykh grupp Russkogo Severa" [Folk medicine of the local groups of the Russian North], Russkii Sever: K probleme lokalnykh grupp, red. T. A. Bernshtam, St. Petersburg, 1995, p. 94; Nizhegorodskie khristianskie legendy (Nizhnii Novgorod Christian legends], Sost., vstup. st. i komm Iu. M. Shevarenkovoi, Nizhnii Novgorod, 1998, p. 49-50; A. V. Tarabukina, "Eskhatologicheskie rasskazy 'tserkovnykh liudei”" [Eschatological stories of church people], Antropologiia religioznosti (Almanakh "Kanun,” vyp.4), St. Petersburg, 1998, p. 397-454; M. N . Vlasova, Russkie sueveriia: Entsiklopedicheskii slovar [Russian superstitions:

Encyclopedic dictionary], St. Petersburg, 1998, p. 16-22; M. N. Vlasova, "Tolki krestian o komete 1899 goda" [Hearsay of the peasants about the comet of 1899], Antropologiia religioznosti (Almanakh "Kanun," vyp. 4), St. Petersburg, 1998, p. 386-96; "Sviashchennoe pisanie v narodnykh pereskazakh" [Holy scripture in folk paraphrases], predislovie E.V. Kuleshova, podgotovka teksktov E. Dankovoi i K Maslinskogo, Zhivaia Starina, 1999, no. 2, p. 45; V.V. Shevelev, "Kon-kamen” [The horse-stone], Zhivaia Starina, 1999, no. 2 , p. 49.

3. Questions about the correlation between apocrypha eschatology and Russian religious verses (stikhi dukhovnye) have been examined by V. Sakharov in his book Eskhatologicheskie sochineniia i skazaniia v drenerusskoi pismennosti i vliianie ikh na russkie dukhovnye stikhi [Eschatological works and legends in Old-Russian literature and their influence on Russian religious verses], Tula, 1879). However, the author did not touch the problem of peasant "rumors and hearsay" about the end of the world.

4. A. F. Belousov, "Poslednie vremena" [The last days], in Aequinox: Sb. pamiati o. Aleksandra Menia, Moscow, 1991, p. 9-33.

5. Op. cit., p. 13.

6. With the exception of a pseudo-evident observation that the Old Believer bespopovtcy "have lived from the very beginning on the eve of the end of the world, in the cheerless atmosphere of the 'Antichrist's reign' which began with the establishment of heretical 'innovations' in the Russian Church" (Op. cit., p. 9). Thus it is supposed that a discussion about the signs of the end of the world is natural for 
the culture of the bespopovtcy. However, in actual fact it turns out that the state of eschatological expectation can be regarded as the main determinant for the picture of the world for present day Orthodox "church people" (A. V. Tarabukina, Eskhatologicheskie rasskazy tserkovnyx liudei [Eschatological stories of the "church people"], p. 397-454). Eschatological stories are also widespread among Russian peasants and townspeople who have a low level of knowledge about the church.

7. V. M. Istrin, "Otkrovenie Mefodiia Patarskogo i apokrificheskie videniia Daniila v vizantiiskoi i slavianorusskoi literaturakh" [The revelation of Methodius of Patar and the apocryphral visions of Daniel in the Byzantine and Russo-Slavic literatures], Issledovaniia i teksti, I, Otkroveniie Mefodiia Patarskogo, Chteniia v obshchestve istorii i drevnostei rossiiskikh, 1897, kn. 2 (181), otd. III. p. 209.

8. It should be added that similar citations can be discovered in the oral folk tradition and also, for example, in Old Believers' polemical written tradition. In one of the Old Believer manuscripts V. M. Istrin discovered a statement about the negative characteristics of making the cross with three fingers which was supposedly present in the "Revelation of Methodius of Patar: "In the last days people will pray with trinity, that is, with three fingers without the embodiment of God's Son and for that they will be condemned to eternal torment ..." (Op. cit., p. 247).

9. Sviashchennoe pisanie v narodnykh pereskazakh [Holy scripture in folk paraphrases], p. 45 (recorded in 1996 in the village of Slepnevo, Toropets region, Tver oblast).

10. EUSPb (sound recording no. EU-Khvoin-99-PF-20). Village of Mikheevo, Moshenskoe region, Novgorod oblast 10.07.1999. N. S. Ermolaev, year of birth 1931.

11. EUSPb (sound recording no. EU-Khvoin-99-PF-15). Village of Zadele, Khvoinaya region, Novgorod oblast 07.07.99. V. E. Ivanov, year of birth 1930.

12. Folklore Cabinet of the Philological Faculty of SPbGU. Belozersk collection, 14-25. Village of Nikolskoe, Vashkino region, Vologda oblast, 15.07.98. L. A. Evteshicheva, year of birth 1930.

13. On some aspects of the functioning of a magical written text in traditional culture see my work: "Magicheskoe pismo": k izucheniiu religioznogo folklora" [A magical letter: toward the study of religious folklore], Antropologiia religioznosti (Almanakh “Kanun,” vyp. 4), St. Petersburg, 1998, p. 175-216.

14. EUSPb. (sound recording no. EU-Khvoin-99-PF-20). Village of Mikheevo, Moshenskoe region, Novgorod oblast 10.07.1999. N. S. Ermolaev, year of birth 1931.

15. EUSPb. (sound recording no. EU-Khvoin-99-PF-34). Village of Ustreka, Moshenskoe region, Novgorod oblast 15.07.1999. N. A. Ivanova, year of birth 1927.

16. Nizhegorodskie khristianskie legendy [Nizhnii Novgorod Christian legends], p. 49 (No. 187). Recorded in 1997 in the village of Teplovo, Kulebakino region, Nizhnii Novgorod oblast.

17. EUSPb. (sound recording no. EU-Khvoin-99-PF-27). Village of Shilovo, Khvoinaya region, Novgorod oblast 12.07.99. N. Ia. Ivanov, year of birth 1927 and A. V. Ivanova, year of birth 1926.

18. V. Smirnov, “Otnoshenie derevni k voine,” p. 123. 
19. A. F. Belousov proposes that the source of the image of the earth wound around with web served as "one of the basic motifs of Old Believer eschatology, a motif that depicts the final victory of evil on the eve of the end of the world by ensnaring the earth with the Antichrist's net" (A. F. Belousov, "Poslednie vremena," p. 12). However, it is clear that interpretative and not genetic mechanisms play a dominant role in formation of this image.

20. I. Ia. Porfirev, “Apokrificheskie skazaniia o vetkhozavetnykh litsakh i sobytiiakh po rukopisiam Solovetskoi biblioteki" [Apocryphal legends about Old Testament personages and events according to manuscripts of the Solovki library], Sbornik ORIaS, t. XVII, no.1, 1877, p. 266. Here A. F. Belousov perceives the influence "of the apocalyptic image of the great red dragon" (Revelations 12,3) and also of the eagle "from visions about the last days by the author of the third book of Ezdra which is popular among Old Believers" (Belousov, "Poslednie vremena," p. 14).

21. A. O. Beliaev, "O bezbozhii i Antikhriste" [About atheism and the Antichrist], t.1: Podgotovlenie, priznaki i vremia prishestviia antikhrista, Sergiev Posad, 1898, p. 956; Smirnov, "Otnoshenie derevni k voine," p. 123.

22. Trunov, "Poniatiia krestian Orlovskoi gubernii," p. 41. The image of "birds with iron noses" has also been recorded by Belousov (Belousov, "Poslednie vremena," p. 14)

23. "The Jerusalem Manuscript" (of "The Epistle of Sunday") is the Russian version of the legend about a heavenly letter that had been widespread among various Christian confessions during the Middle Ages.

24. P. A. Bessonov, Kaleki perekhozhie: Sbornik stikhov i issledovanie [Itinerant Singers: A collection of verses and research], vyp. VI, Moscow, 1864, p. 90 (no. 568); compare p. $92-93$ (no. 569).

25. Compare B 15.7.13.1 of the "Motif-index of Folk-literature" by St. Thompson.

26. A. N. Afanasev, Narodnye russkie skazki v trekh tomakh [Folk Russian tales in three volumes], ed. by L.G. Barag and N. V. Novikov, t. II, Moscow: 1985, p. 218-19 (No. 243). Other Russian variants mention "an eagle," "a big bird," or simply "a bird."

27. Op. cit., p. 446-47 (no. 295-96).

28. Skazki Terskogo berega Belogo moria [Tales of the Tersk Shore of the White Sea], ed. D. M. Balashov, Leningrad: 1970, p. 320-23.

29. Compare S. A. Shtyrkov, "Konstruirovanie kollektivnoi istoricheskoi pamiati v lokalnoi traditsii: vozmozhnyi podkhod k postroeniiu interpretatsionnoi modeli" [Contructing collective historical memory in a local tradition: a possible approach to the organization of an interpretive model], in Staroladozhskii sbornik, St. Petersburg: Staraia Ladoga, 1998, p. 128.

30. "Then every woman be be a widow, and seven women will look for a single husband and will not find him; and having heard of this, young boys will come to them from other countries and will begin committing lechery with them like pigs, having no sense" (V. M. Istrin, “Otkrovenie Mefodiia Patarskogo i 
apokrificheskie videniia Daniila v Vizantiiskoi i slavianorusskoi literaturakh,” Teksty: I, “Otkrovenie Mefodiia Patarskogo," Chteniia Obshchestva istorii i drevnostei rossiiskikh, 1897, kn. 4 (183), otd. III, p. 127. Compare A. N. Veselovskii, "Opyty po istorii khristianskoi legendy, II, Legenda o vozvrashshaiushchemsia imperatore" [Studies in the history of Christian legend, II, The legend about the returning emperor], Zhurnal Ministerstva narodnogo prosveshcheniia, 1875, May (ch. CLXXIX), p. 68-69. Compare: "Before the end of the world there will remain as many just people as can find room on a tree seven meters high. When a bear passes by the tree, the women will ask: 'Hasn't my husband come?'” (Mazalova, "Narodnaia meditsina," p. 94).

31. Motif E2A according to N. A. Krinichnaia, Predaniia Russkogo Severa [Legends of the Russian North], St. Petersburg: 1991, p. 281. See also: N. A. Krinichnaia, Russkaia narodnaia istoricheskaia proza: Voprosy genezisa i struktury [Russian folk historical prose: Questions about their genesis and structure], Leningrad: 1987, p. 33-35.

32. Krinichnaia, Predaniia Russkogo Severa, p. 30 (no. 10). Recorded in the village of Ladva, Prionezhskii district, Karelian ASSR.

33. It must be emphasized that in Russian folklore the concepts of ground, land, and earth are expressed by the same term (zemlia) and are often indistinguishable.

34. Nizhegorodskie khristianskie legendy, p. 49 (no. 185); compare: V. Smirnov, "Otnoshenie derevni k voine," p.123. Vershok (1 $3 / 4$ inches) and piad (span of the hand) are ancient Russian linear measures.

35. Belousov, "Poslednie vremena," p. 32.

36. See the materials on this problem collected by A. V. Svirnovskaya in her essay "Izmerenie tela: identifikatsionnye praktiki" [Measuring the body: Identification practices], in Mifologiia i povsednevnost, vyp.2 : Materialy nauchnoi konferentsii 24-26 February 1999, compiled and edited by K.A. Bogdanov and A.A. Panchenko, St. Petersburg: 1999, p. 79-80.

37. Nizhegorodskie khristianskie legendy, p. 49 (no. 185).

38. EUSPb, (sound recording no. EU-Khvoin-99-PF-27). Village of Shilovo, Khvoinaya region, Novgorod oblast 12.07.99. N. Ia. Ivanov, year of birth 1927 and A. V. Ivanova, year of birth 1926.

39. See Beliaev, “O bezbozhii i Antikhriste," p. 955-59.

40. Op. cit., p. 957.

41. Belousov, "Poslednie vremena," p. 21-22.

42. Eschatological stories about the Antichrist developed in the twentieth century in "intra-church" folklore and among educated Old Believers. See: A. V. Tarabukina, "Eskhatologicheskie rasskazy," and L. S. Soboleva, "Amerikanskoe sochinenie ob Antikhriste-kompiutere v interpretatsii uralskogo starovera" [An American work about the Antichrist computer in the interpretation of an Old Believer from the Urals], in 
Issledovaniia po istorii knizhnoi i traditsionnoi narodnoi kultury Severa: Mezhvuzovskii sbornik nauchnykh trudov, Syktyvkar, 1997, p. 118-30.

43. See: M. Eliade, Aspekty mifa [Aspects of myth], Moscow: 1995, p. 62-68.

44. EUSPb, (sound recording no. EU-Khvoin-99-PF-27). Village of Shilovo, Khvoinaya region, Novgorod oblast 12.07.99. N. Ia. Ivanov, year of birth 1927 and A. V. Ivanova, year of birth 1926.

45. See: K. V. Chistov, Russkie narodnye sotsialno-utopicheskie legendy XVII -XIX vv. [Russian folk social-utopian legends of the seventeenth to the nineteenth centuries], Moscow, 1967, and Narodnye traditsii i folklor: Ocherki teorii [Folk traditions and folklore: Essays on theory], Leningrad, 1986, p. 189246.

46. Sviashchennoe pisanie v narodnykh pereskazakh, p. 45 (recorded in 1996 in the village of Nagove, Toropets region, Tver oblast)..

47. EUSPb, (sound recording no. EU-Khvoin-99-PF-15). Village of Zadele, Khvoinaya region, Novgorod oblast 07.07.99. V. E. Ivanov, year of birth 1930.

48. Chistov, Narodnye traditsii i folklor, p. 230.

49. Chistov, Russkie narodnye sotsialno-utopicheskie legendy, p. 327-40.

50. See, for instance: G. A. Fine, "The Third Force in American Folklore: Folk Narratives and Social Structures,” Fabula, 1988, Bd. 29, Heft 3/4, p. 342-53.

51. See: M. Eliade, Mefistofel i androgin, St. Petersburg, 1998, p. 206-32.

52. In this connection, it is worth mentioning the ideas of the Dutch scholar S. Brower who compares the stereotypes of conduct and the ideologemes of the early Russian intelligentsia in the nineteenth century with the cargo-cults: S. Brouver, "Paradoksy rannei russkoi intelligentsii (1830-1850): natsionalnaia kultura versus orientatsiia na Zapad" [Paradoxes of the early Russian intelligentsia (18301850): national culture versus orientation to the West], in Russkaia intelligentsiia i zapadnyi intellektualizm: Istoriia i tipologiia, compiled by B. A. Uspenskii, Rossiia/Russia, novaia seriia, no. 2 (10), Moscow: Venice, 1999, p. 49-66. 